\title{
Sex-oriented research on dioecious crops of Indian subcontinent: an updated review
}

\author{
Sutanu Sarkar $^{1,2} \cdot$ Joydeep Banerjee $^{1,3} \cdot$ Saikat Gantait $^{1,4}$ (B)
}

Received: 23 May 2016/Accepted: 6 April 2017/Published online: 29 May 2017

(C) Springer-Verlag Berlin Heidelberg 2017

\begin{abstract}
A number of dioecious species are grown across India and some of those plants play a crucial role in the agrobased economy of the country. The diagnosis of sex is very difficult in the dioecious plant prior flowering wherein sex identification at the seedling stage is of great importance to breeders as well as farmers for crop improvement or production purpose. A comprehensive approach of sex determination comprising morphological, biochemical, cytological and molecular attributes is a must required for gender differentiation in dioecious plant species. In the present review, we highlighted the economical, medicinal as well as industrial importance of most of the dioecious species extensively grown in Indian subcontinent. In addition to that, the cytogenetic, genetic as well as molecular information in
\end{abstract}

Sutanu Sarkar and Joydeep Banerjee share equal contribution.

Saikat Gantait

saikatgantait@yahoo.com

Sutanu Sarkar

sutanumax@gmail.com

Joydeep Banerjee

jbanerjeebiotech@gmail.com

1 Department of Genetics and Plant Breeding, Faculty of Agriculture, Bidhan Chandra Krishi Viswavidyalaya, Mohanpur, Nadia, West Bengal 741252, India

2 Crop Research Unit, Bidhan Chandra Krishi Viswavidyalaya, Mohanpur, Nadia, West Bengal 741252, India

3 Survey, Selection and Mass Production, Bidhan Chandra Krishi Viswavidyalaya, Mohanpur, Nadia, West Bengal 741252, India

4 All India Coordinated Research Project on Groundnut, Bidhan Chandra Krishi Viswavidyalaya, Kalyani, Nadia, West Bengal 741235, India connection to their sex determination were critically discussed in this review.

Keywords Dioecy · Economic importance - India · Medicinal value $\cdot$ Molecular markers $\cdot$ Sex determination

\section{Introduction}

Monoecious plants possess independent male and female flowers on the same plant whereas dioecious plants bear male (staminate) and female (pistillate) flowers in different plants. Dioecy is available only in $\sim 7 \%$ of flower-bearing plants that cover $\sim 38 \%$ plant families (Renner and Ricklefs 1995). Additionally, the occurrence of dioecy is greater among the dicot plants compared to the monocot plants (Ainsworth 2000). It is expected that dioecious species evolved from hermaphrodites or monoecious individuals through two independent mutations resulting in male sterility and reducing female fertility and that ultimately led to functional dioecy (Charlesworth 1991). The most widely accepted hypothesis regarding dioecy evolution is to escape from inbreeding (Barrett 2002). Diverse mechanisms to promote outcrossing include differential maturity of male and female reproductive parts, gametophytic as well as sporophytic selfincompatibility, development of heteromorphic flowers, creation of monoecy and ultimately formation of dioecy. Additionally, it is also expected that the dioecious plants originated from self-compatible species rather than from self-incompatible parents (Barrett 2013).

Generally, three different concepts are available concerning the sex determination in dioecious species viz. hormonal control, epigenetic control and genetic control. Several reports meticulously presented the involvement of diverse phytohormones like gibberellins, ethylene, auxins 
and cytokinins in sex expression of some dioecious plants (Ming et al. 2007, 2011; Milewicz and Sawicki 2012). In some dioecious plants like Silene latifolia, Melandrium album and Cannabis sativa, epigenetic regulation of sexdetermination was reported (Law et al. 2002; Soldatova and Khryanin 2010; Milewicz and Sawicki 2012). Several studies were carried out for considering the genetic control of sex determination in dioecious plants. The genetic control of sex determination may be single locus or multiple loci controlled. In case of multiple loci governed sex determination system chromosome constituents may be either homogametic or heterogametic in nature. In Atriplex garrettii and Ecballium elaterium (squirting cucumber), a single locus determines the sex of the plants whereas in Mercurialis аппиа, sex is controlled by multiple unlinked loci (Heikrujam et al. 2015). In several dioecious species including white campion (S. latifolia), asparagus (Asparagus officinalis L.), date palm (Phoenix dactylifera L.), palmyra palm (Borassus flabellifer L.), pointed gourd (Trichosanthes dioica Roxb.), teasle gourd, ivy gourd (Coccinia indica Wight and Arn. and C. grandis (L.) Voigt), kiwifruit (Actinidia deliciosa var. deliciosa) and hemp (C. sativa L.) homogametic female (XX) and heterogametic male (XY) plants were documented (Ming et al. 2007; Cherif et al. 2013) but, a recent study also reported supermales (YY) in asparagus (Harkess et al. 2015). In papaya (Carica papaya), which is trioecious in nature due to availability of three sex types (male, female and hermaphrodite), $\mathrm{XY}$ system is available and two distinct $\mathrm{Y}$ chromosomes viz. $\mathrm{Y}$ and $\mathrm{Y}^{\mathrm{h}}$ were reported. $\mathrm{Y}$ chromosome determines the development of male flowers whereas $\mathrm{Y}^{\mathrm{h}}$ chromosome, which is $1.2 \%$ diverse than the $\mathrm{Y}$ chromosome at DNA level, governs hermaphrodite flower development (Wang et al. 2012). In contrast to the XX female and $\mathrm{XY}$ male plants mentioned earlier, certain dioecious species like pistachio, yam, nutmeg, wild strawberry (Fragaria elatior) and willow (Salix viminalis) were found to have heterogametic female (ZW) and homogametic male (ZZ) chromosomes (Hormaza et al. 1994; Vyskot and Hobza 2004; Kafkas et al. 2015). In some dioecious species like sorrel (Rumex acetosa) and hops (Humulus japonicas, H. lupulus) not only the sex chromosome but the balance between the sex chromosome and autosome (X:A) governs the sex of the plant (Ainsworth et al. 2005; Shephard et al. 1999, 2000). Under that category, female sex possesses X:A ratio greater or equal to 1.0 but for male sex, the $\mathrm{X}$ :A ratio is lesser or equal to 0.5 .

Different modes of sex chromosome evolution and their modifications were documented by several researchers (Vyskot and Hobza 2004; Ming et al. 2011) and Fig. 1 depicts the fact that how sex chromosomes of plants were evolved. Although several researches were carried out to unravel the genetic mystery regarding the sex determination in plants, there is very little genomic information available for dioecious species. To our knowledge, among the major dioecious species the genetic maps for the sex chromosome are available only in case of $H$. lupulus, asparagus and kiwifruit (Telgmann-Rauber et al. 2007; Seefelder et al. 2000; Fraser et al. 2009), while sex-linked genes were mapped in Silene species (Bergero et al. 2013). A study in Rumex hastatulus revealed the distribution of cytonuclear interacting genes (genes from nucleus, mitochondria and chloroplast) with sex chromosomes (Hough et al. 2014). A recent review aptly presented several discoveries regarding the sex determination in dioecious plants at genetic and chromosomal level and updated about different sex-specific genes in monoecious as well as dioecious plants (Kumar et al. 2014). Further research is needed to understand the molecular basis of sex determination in model as well as cultivated dioecious plants grown worldwide. In this present review, we focused on the economically important dioecious plant species grown in India, their medicinal or commercial utilities as well as several key studies regarding their sex determination. The names of those dioecious species (under discussion) have been presented in Table 1 along with the major Indian states producing those crops.

\section{Pointed gourd (Trichosanthes dioica Roxb.)}

Pointed gourd (T. dioica Roxb.), commonly known as parwal (in India), belongs to the family Cucurbitaceae. It is a perennial crop extensively grown in tropical and subtropical parts of the world. It holds a stable position at Indian vegetable market for more than 8 months including kahrif and rabi seasons (Banu et al. 2007; Shivhare et al. 2010). It is also called as 'green potato' or the 'king of gourd' because of its wider acceptance as vegetables with nutritive values. Vitamin $\mathrm{C}$ content of pointed gourd is much higher than that of any other gourd. The pointed gourd has numerous medicinal values in its fruit, stem and leaves. The leaves have blood sugar improvement properties (Rai et al. 2008) and the juice extracted from the leaf is used to treat alopecia areata affected patches (Prajapathi et al. 2003). The fruit is diuretic in nature and used for improving appetite as well as digestion and in addition to that it possesses cardiotonic, antiulcerous and anthelmentic properties. The fruit can also reduce blood sugar and serum triglycerides levels in the body and can be used against spermatorrhoea and skin diseases (Sharma et al. 1990). The tender shoots and juice of unripe fruits are used as laxatives. The fruits as well as seeds have some anticancer and haemagglutinating activities while the seeds are reported to have antidiabetic activity (Rai et al. 2010). The decoction is useful in skin diseases and used as a febrifuge. Another 


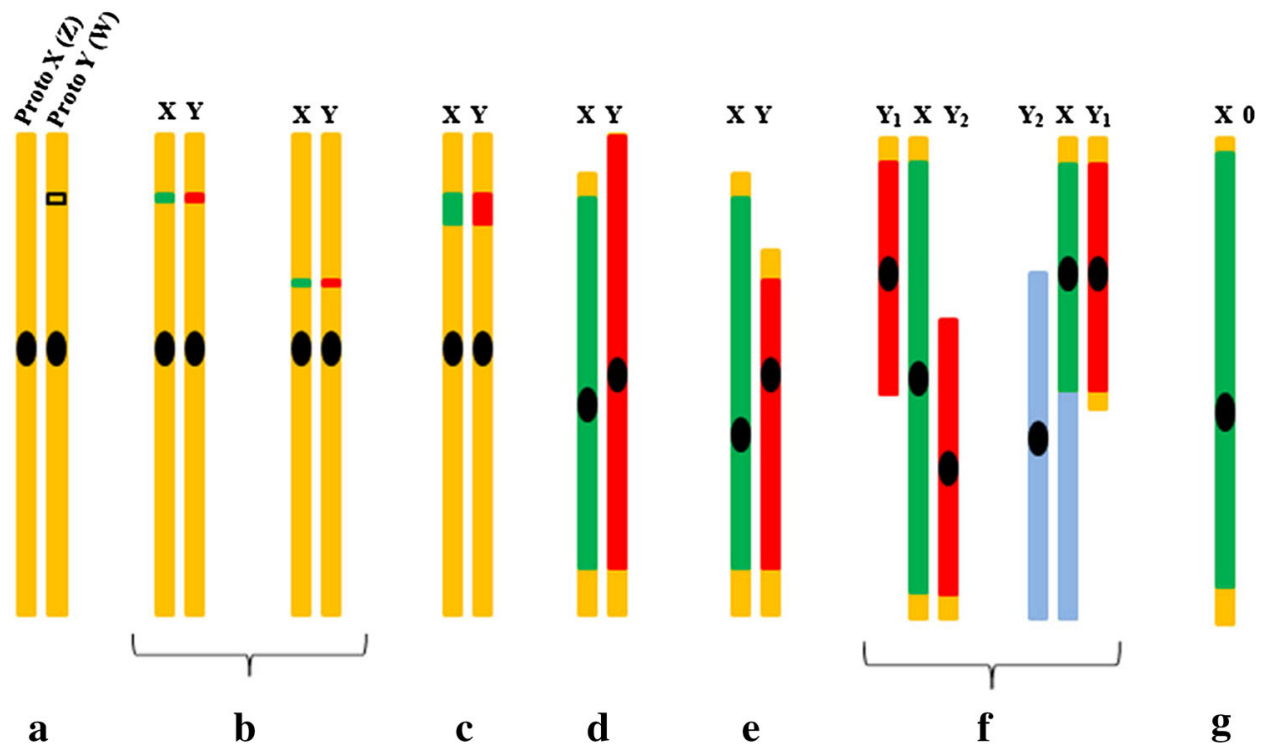

- Centromeric region

- Autosomal or pseudo-autosomal region (PAR)

- Male sterile and female sterile mutation

- Male-specific region on Y chromosome (MSY)

- Region corresponding to MSY on X chromosome

\section{Autosome or translocated autosome}

Fig. 1 A schematic diagram of plant sex chromosome evolution that confirms the pivotal role of $\mathrm{Y}$ chromosome for the maleness in dioecious plant species. It can be illustrated as follows: $\mathbf{a}$ in the $\mathrm{XY}$ or ZW system, mutation causing functional loss in one chromosome and subsequently conferring complementary dominance to its homologue. As a result, either male or female sterility is induced. Here, recombination among the sex-determining loci produces many hermaphrodites and neuters also; $\mathbf{b}$ a small male-specific region on $\mathrm{Y}$ chromosome (MSY) is developed as a result of suppression of recombination between the sex-determining loci. As a result, the YY males can be found; $\mathbf{c}$ here the MSY continues to expand due to duplication of Y-linked genes or accumulation translocation products

study in rats reported that the fruit extract of pointed gourd possesses wound healing and cholesterol-lowering activity (Banu et al. 2007; Shivhare et al. 2010).

Owing to the poor seed viability and germinability, vine and root cutting are recommended for commercial propagation. The major insect pollinator of pointed gourd is red brown beetle (Carpophilus dimidiatus), but in India, hand pollination is done for better fruit set in this dioecious crop (Hazra et al. 2011). The chromosome number of pointed gourd was reported to be $2 n=22$ from both sex without having any distinct sex chromosome (Sinha et al. 2007). A noticeable proportion for female plants over males (2.4:1) was observed by Kumar et al. (2008) by in vitro culture of and transposons causing loss of many genes; therefore, YY genotypes cannot be found in the population; $\mathbf{d}$ in this case the MSY occupies majority of the $\mathrm{Y}$ chromosome causing elongation of $\mathrm{Y}$ chromosome than the $\mathrm{X}$ homologue, i.e. they become heteromorphic; e shrinkage of $\mathrm{Y}$ chromosome occurs due to deletion of many nonfunctional genes; $\mathbf{f}$ due to translocation of autosomal segment into the $X$ chromosome and its co-segregation with the normal $\mathrm{Y}$ homologue afterwards generates a multiple $\mathrm{Y}$ chromosome system (XY1Y2); g the entire $\mathrm{Y}$ chromosome suffers no recombination causing complete loss of $\mathrm{Y}$ from the genome and $\mathrm{X}$-to-autosome ratio for sex determination system arises

almost fully developed embryos; the probable cause might be due to the action of lethal/sub-lethal gene(s) linkage with the female sex confirming locus. Hazra et al. (2011) reported a pair of physiologically distinct chromosomes carrying the sex determining genes in pointed gourd, whereas later on, Karmakar et al. (2013) karyotyped another dioecious Trichosanthes ( $T$. bracteata) revealing the absence of XY mechanism.

During the last one and half decade, a number of researches were carried out employing the molecular marker-based sex determination in Trichosanthes species. Although Singh et al. (2002), for the first time, reported a female-specific 567 base pair (bp) amplicon using randomly amplified polymorphic

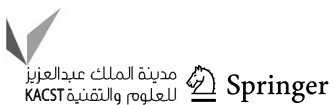


Table 1 Economically important dioecious crops grown in different states of India

\begin{tabular}{|c|c|c|}
\hline Dioecious plants & Major growing states & Major economic importance in India \\
\hline Trichosanthes dioica & West Bengal, Assam, Tripura, Arunachal Pradesh, Orissa, Jharkhand and Bihar & Used as vegetable \\
\hline Coccinia species & West Bengal, Tripura and Assam & Used as vegetable \\
\hline Momordica species & West Bengal, Assam and Tamil Nadu & Used as vegetable \\
\hline Asparagus & Himachal Pradesh & Used as vegetable \\
\hline Betel vine & West Bengal, Andhra Pradesh, Kerala, Assam, Tamil Nadu and Karnataka & Used as masticatory \\
\hline Long pepper & Kerala and Andhra Pradesh & Used as spice \\
\hline Nutmeg & Kerala, Tamil Nadu and Karnataka & Used as spice \\
\hline Pistachio & Jammu \& Kashmir and Himachal Pradesh & Used as condiment \\
\hline Date palm & Rajasthan, Gujarat and Punjab & Used as fruit \\
\hline Palmira palm & Kerala & Used as fruit \\
\hline Rattan palm & Assam and Arunachal Pradesh & Used to make furniture \\
\hline Mulberry & Karnataka, Andhra Pradesh, West Bengal, Tamil Nadu and Jammu \& Kashmir & Used in silk industry \\
\hline Kiwifruit & Himachal Pradesh & Used as fruit \\
\hline Pandanus species & Orissa and West Bengal & Used as condiment \\
\hline Jojoba & Rajasthan & Used in oil and cosmetic industry \\
\hline Yam & Orissa & Used as starchy food \\
\hline Hemp $^{\mathrm{a}}$ & - & - \\
\hline
\end{tabular}

${ }^{\text {a }}$ Cultivation of hemp in India is prohibited by law

DNA (RAPD) primer (OPC07), the same primer failed to reproduce that particular band in a local popular variety (Kajli) of $T$. dioica in our experiment (unpublished data). Hence, an uncertainty remains on using OPC07 to screen the female plants of pointed gourd. Further studies identified three polymorphic RAPD markers for sex determination in pointed gourd viz. OPC05 amplified 1000 bp for male plant, OPC14 amplified $400 \mathrm{bp}$ for female plant and another one (OPN01) showed $1030 \mathrm{bp}$ amplification in both male and female plants but did not produce any band in the parthenocarpic plants (Kumar et al. 2012). From one inter-simple sequence repeat (ISSR) marker, Nanda et al. (2013) resized a sequence-tagged site (STS) marker (TdSTSM) that could amplify $720 \mathrm{bp}$ amplicon in the male flower bearing plants only. Additionally, the amplified region was used in Southern blotting to confirm the single copy male-specific locus in pointed gourd. Recently, another group of scientists screened 42 ISSR primers to reveal the sex differentiation in pointed gourd (Adhikari et al. 2014); out of these primers, only ISSR-6 with the sequence $(\mathrm{GACA})_{4}$ showed $\sim 500$ bp amplification distinctly in male plants.

\section{Ivy gourd (Coccinia species)}

Ivy gourd ( $C$. indica Wight and Arn. and $C$. grandis (L.) Voigt), another important member of Cucurbitaceae, is also known as kundru (in India). It is a rapidly growing perennial climber which is vegetatively propagated and widely cultivated in India. The whole plant of $C$. grandis was found to possess numerous pharmacological activities including antibacterial, hepatoprotactive, antitussive, antioxidant, hypoglycaemic, antimalarial, antihelminthic, anticancerous, antidyslipidemic, antiinflammatory, analgestic, antipyretic, alpha amylase inhibitory activity, etc. (Tamilselvan et al. 2011; Hussain et al. 2011; Pekamwar et al. 2013). Ivy gourd is rich in $\beta$-carotene and traditionally it is widely used in folklore medicine against diabetes, ulcers, stomach ache, skin disease, fever, cough, asthma, jaundice, wound healing, anaemia and gonorrhoea (Hussain et al. 2011). Following some literatures, the somatic chromosome number may be $2 n=24,36$ or 48 (Guha et al. 2014; Ghadge et al. 2014) while according to other reports the male plants are heterogametic with $22+\mathrm{XY}$ and the female are homogametic with $22+\mathrm{XX}$ (Sinha et al. 2007; Sousa et al. 2013). According to Guha et al. (2014), the Y chromosome is noticeably 3-4 times larger than almost all of the other chromosomes but karyotyping of $C$. grandis revealed the size of the Y chromosome twice of any other chromosomes and its complete heterochromatic nature was documented by C-banding (Sousa et al. 2013). Additionally, fluorescence in situ hybridization (FISH) staining revealed the absence of $5 \mathrm{~S}$ and $45 \mathrm{~S}$ rDNA sites on the $\mathrm{Y}$ chromosome and genomic in situ hybridization (GISH) using various femaleness blocking DNA concentrations, discovered the possibility of the presence of pseudo-autosomal region on it (Sousa et al. 2013). According to Ghadge et al. (2014), Y chromosome possesses the pollen fertility factor as well as the region containing 'female suppressing' functions in $C$. grandis. 
Very little work has been performed on Coccinia species regarding the identification of sex-related molecular marker. In a study conducted by Bhowmick et al. (2014), a male-specific RAPD marker (designated as CgMSM) was identified in $C$. grandis. Out of nineteen RAPD primers tested, only the primer OPC08 produced a male-specific amplification of $\sim 830 \mathrm{bp}$. One sequence characterized amplified region (SCAR) marker (CgY1) with 829 bp amplification was also developed in that study which was available in male plants only.

\section{Momordica species}

There are four dioecious species under the genera $\mathrm{Mo}$ mordica and all of them are from the family Cucurbitaceae; the first three viz. $M$. dioica Roxb., $M$. sahyadrica, and $M$. cochinchinensis (Lour.) Spreng. have $2 n=28$ and the fourth one i.e. M. subangulata Blume subsp. renigera (G. Don) has $2 n=56$ (Bharathi et al. 2011) chromosomes. They are perennial creepers and propagated vegetatively through tuberous roots. Due to the presence of deep red colour in the aril, i.e. seed pulp, for the availability of considerably more carotenoid, the ripe gac (M. cochinchinensis) fruit is massively used to colour the rice grains by the Vietnamese (Aoki et al. 2002; Vuong et al. 2006). Zheng et al. (2014) proved the anticancerous property of gac seeds. In India, sweet gourd or gac fruit is an underutilized vegetable but the other three are popularly known as kantola or spine gourd or teasle gourd and fruit; young twigs as well as leaves are widely consumed as vegetables.

The $M$. dioica has several medicinal uses (Talukdar and Hossain 2014). Dried fruit powder produces a powerful errhine effect when applied into the nostrils. Fresh fruit juice is consumed against hypertension and diabetes and extract from the leaves is applied as ointment to relieve headache while the leaf paste can be used against the eczema and other skin problems. To treat snakebite and scorpion sting, the root of the male plant is used while the tuber of female plant and toasted root are used to treat bleeding piles and bowel infections. The tubers of the teasle gourd act as antihelminthic, spermicidal, and antifertility as well as abortifacient agent. Beside these, it has antioxidant, analgesic, nephroprotective, neuroprotective, antiallergic, antiulcer, anticancer, antimicrobial, antimalarial, hepatoprotective, antihepatotoxic, antiedemic and insecticidal properties (Talukdar and Hossain 2014). Narasimhan et al. (2005) showed antifeedant activity of $M$. dioica against Spodoptera litura and the seed oil of $M$. dioica could be used as grain protectant against Callosobruchus chinensis (Mishra et al. 2006). Later on, Ahire and Deokule (2012) showed the allelopathic activity of $M$. dioica on Phaseolus aconitifolius Jacq.
An attempt was made for the first time to understand the genotypic differentiation between male and female plants of $M$. dioica at molecular level using RAPD primers (Baratakke and Patil 2009). Out of 20 RAPD primers tested, only OPA-15 showed unique male-specific $1625 \mathrm{bp}$ amplification. Subsequently, the same group screened 50 RAPD primers and among them only OPA-15 showed male-specific amplification as detected earlier but the amplicon size was $\sim 1500 \mathrm{bp}$. Using the sequence information of the male-specific $1500 \mathrm{bp}$ band, two SCAR primers viz. MSSM-01F and MSSM-01R were developed which could specifically amplify 1501 bp DNA only from the male plants but not from the female plants (Patil et al. 2012).

\section{Garden asparagus (Asparagus offcinalis L.)}

Garden asparagus (A. officinalis L.), a plant from the Asparagaceae family, is herbaceous perennial plant and it is propagated through seeds. The tender succulent shoots are eaten as vegetable that is nutritious and rich in vitamins. The tender shoots or spears are cooked as vegetable, soup and it can be eaten raw (Kabir 1993). Although they are dioecious but $1-2 \%$ plant are andromonoecious carrying hermaphrodite and male flowers on the same plant (Telgmann-Rauber et al. 2007). The male flowers are yellowish green and conspicuous, while the female flowers are less conspicuous. Male asparagus plants are comparatively more disease resistant, have better yields and live longer than female plants (Kabir 1993) and also they do not produce seeds to create 'asparagus weed problem'. According to Harkess et al. (2015), the chromosome number of diploid asparagus is $2 n=20$ with $x=10$. The females, males and supermales have XX, XY and YY sex chromosomes, respectively, and specifically males as well as supermales possess genes involved in pollen microspore and tapetum development.

As asparagus has a global market and male plants are preferred compared to the female plants by the growers, several studies were carried out for identifying different sex-specific molecular markers in this crop. A total of 760 RAPD primers were used by Jiang and Sink (1997) to explore the male sex locus $M$ of asparagus using a mapping population and only one primer (OPC15) showed two polymorphisms (OPC15-98 and OPC15-30) specific to sex locus $M$. Using the sequence information of OPC15-98 marker, an SCAR primer was developed which could amplify 980 bp specific region from the male plants only. Interestingly, the SCAR marker was not found suitable for other asparagus germplasm studied by the same group (Jiang and Sink 1997). In the following year, another group identified amplified fragment length polymorphism (AFLP) 
marker E41M50 providing strong male-specific linkage in A. officinalis (Reamon-Büttner et al. 1998). Later on, nine AFLP markers (showing sex linkage) and two STS markers were used to identify 13 different bacterial artificial chromosome (BAC) clones generated from one male plant carrying the male flowering gene at homozygous state (MM) (Jamsari et al. 2004). Using the Asp1-T7 marker, previously used by Jamsari et al. (2004), a PCR based marker pair (Asp1-T7spf and Asp1-T7spr) was generated, which could produce $308 \mathrm{bp}$ amplicon specific for maleness (Nakayama et al. 2006). Using the RAPD primer S368, Gao et al. (2007) identified two different femalespecific markers (S368-928 and S368-1178). Between these two markers, S368-928 was found to be linked with the female sex locus and using the sequence information an SCAR marker was developed to identify homozygous female $(\mathrm{mm})$ plant. Interestingly, Southern blot analysis revealed that the genomic region corresponding to S368928 was found to be available in both the sexes (male and female). Another RAPD primer (T35R54) amplified 1600 bp male-specific region between the tested supermale and normal male plants (Ii et al. 2012). Kanno et al. (2014) derived a male-specific STS from the T35R54-1600 and it was identified as another sex-linked region. The identified primer pair (MSSTS710-fw and MSSTS710-rv) amplified 710 bp male-specific amplicon in eight different cultivars of A. officinalis. Although the earlier reported Asp1T7sp marker (Nakayama et al. 2006) was able to generate malespecific amplifications in two different species of asparagus, namely A. schoberioides and A. kiusianus, MSSTS710 failed to show any amplification in those two species (Kanno et al. 2014).

\section{Betel vine (Piper betle $\mathrm{L}$. )}

This is a cash crop in India (commonly known as paan) from the family Piperaceae. It is a perennial and vegetatively propagated evergreen creeper favouring tropical forest climate having shade, high humidity and warm temperature. It has a wide range of somatic chromosome number $(2 n=45,48,52,56,64,72)$ and according to Samantaray et al. (2012), males are triploids $(3 x=39)$ whereas females are tetraploids $(4 x=52)$. Leaves of female plants are mostly pungent and are cordate or ovate to round in shape whereas in case of male plants the leaves are non-pungent and are narrowly ovate. Two types of branches are produced in betel vine, namely orthotropic (vegetative) and plageotropic (reproductive). The male and female spikes are long and short, respectively, and those arise singly from the leaf base (Maiti 2006).

Various compounds, namely chavicol, hydroxyl-chavicol, chavibetol and chavibetol acetate were identified from betel leaves possessing medicinal values to cure digestive problems and were used for healing wounds, burns, gum sores as well as to prevent cancer (Rai et al. 2011). Betel leaves are also utilized in various Hindu religious purposes and it has great economic importance as it is taken as regular post-meal item masticated by many Indian people.

Since the last decade, researches have carried out sexspecific molecular marker identification in this important commercial horticultural crop of Southeast Asia. Different RAPD primers, especially OPB-08, OPF-09, OPF-07 and OPG-16, showed differential banding pattern among the male (Desavari) and female (Bangla) plants of $P$. betle (Usha et al. 2009). Another group identified 1400 and $850 \mathrm{bp}$ male-specific amplification using OPA04 and OPN02 RAPD primers, respectively, and $980 \mathrm{bp}$ femalespecific amplifications using OPC06 primer; additionally PCR amplification using RAPD primer OPA08 generated 650 bp amplicon only in male DNA samples and $1200 \mathrm{bp}$ PCR product only in female DNA samples (Samantaray et al. 2012). Further researches identified two amplicons viz. 459 and $1250 \mathrm{bp}$, specific for maleness, using ISSR primers ISSR-10 [(GA) $\left.{ }_{6} \mathrm{CC}\right]$ and UBC-852 [(TC $)_{8} \mathrm{RA}$ ], respectively and a female-specific amplification of $636 \mathrm{bp}$ fragment using ISSR-23 [(GACA) $\left.)_{3} \mathrm{CC}\right]$ primer (Khadke et al. 2012). Using the female-specific amplicon produced by ISSR-23 primer, a successful attempt was made to develop a SCAR marker (primers designated as IS-23 F/R) that could amplify a 636 bp band only in female plants but not in males. Another group developed a SCAR marker derived from a RAPD marker for the first time in betel vine (Sheeja et al. 2013). Out of 82 RAPD primers, primer OPE11 obtained a male-specific amplification of about $600 \mathrm{bp}$ whereas the primers OPE-1 and OPB-20 showed femalespecific amplifications of about 400 and 488 bp, respectively. A female-specific SCAR marker (primer used: Pibet-20 F and Pibet-20 R) having the accession number JN228255 was developed using the 488 bp female-specific amplicon obtained by the primer OPB-20 (Sheeja et al. 2013).

\section{Long pepper (Piper longum L.)}

Long pepper (Piper longum L.), popularly known as Pipal in India, belongs to the family Piperaceae. It is a slender aromatic perennial climber and is well known for its medicinal property. The plant is propagated through seeds, suckers or cuttings. The somatic chromosome number is $2 n=24,48,52,96$ (Farooqi et al. 2005). Female spikes are shorter and thicker than the male spikes and mature female spikes are extensively used against respiratory tract diseases traditionally in Indian Ayurveda (Viswanathan 1995). The dried fruit is used as a spice, while the roots or 
Piplamul are used both in ayurvedic and Unani systems of medicine. The root and fruit are used in palsy, gout and lumbago whereas the roots are used to cure abdominal problems, spleen diseases and tumour also (Farooqi et al. 2005).

The first attempt to identify sex-specific molecular marker in $P$. longum was carried out by Banerjee et al. (1999) using RAPD primers and among the tested primers OPA-10 and OPAC-12 showed male-specific amplification of around 908 and 757 bp, respectively. Further studies identified two other male sex-associated amplifications of around 827 and 744 bp using RAPD primers OPA10 and OPA15, respectively (Manoj et al. 2005). Furthermore, using these amplifications two SCAR markers were developed and the amplicons are available in the GenBank, NCBI having accession numbers AY046931 and AF375880. The pair of SCAR markers (MPS1A and MPS1B) could amplify the sequence MADP1 (malespecific DNA) having accession number AY046931 specifically from the male-specific DNA samples only, whereas the SCAR marker based on MADP2 sequence showed 744 and $747 \mathrm{bp}$ amplifications from male and some of the female plants, respectively (Manoj et al. 2005). Moreover, the same group identified several sex-specific molecular markers (3 male-specific and 8 female-specific) by polymerase chain reaction (PCR) based approach.

\section{Nutmeg (Myristica fragrans Houtt.)}

Nutmeg tree (Myristica fragrans Houtt.) or jaephal (common name in India) comes under the family Myristicaceae and produces two separate spices from the fruit, namely nutmeg and mace; the dried seed kernel is called nutmeg whereas mace is the dried aril covering the single seed. It is a spreading evergreen tree with somatic chromosome number $2 n=42$ and can be propagated vegetatively mainly by grafting or from seeds (Farooqi et al. 2005). It has been suspected that a female heterogametic system ( $\mathrm{ZZ}$ male and $\mathrm{ZW}$ female) exists in nutmeg (Heikrujam et al. 2015). The male has smaller and fewer leaves than the female. Although nutmeg and mace are largely used as flavouring agent, several studies reported the potential utility of nutmeg as antibacterial, antiviral, antidiabetic, and antileukaemic agents (Farooqi et al. 2005; Latha et al. 2005; Yang et al. 2006; Chirathaworn et al. 2007).

Almost 6-8 years is needed to differentiate the sex in $M$. fragrans. The female plants are economically productive and early detection of sex is needed to reduce the male plants about up to $50 \%$ of the population. Till date to our knowledge only a single report is available regarding the availability of sex-associated molecular marker in this tree species. Out of 60 different RAPD primers tested, only the primer OPE 11 produced a female-specific $\sim 416 \mathrm{bp}$ amplification in nutmeg, but the same band was not detected in male samples (Shibu et al. 2000).

\section{Pistachio (Pistacia vera $\mathbf{L}$.)}

Pistachio (Pistacia vera L.) or pista (common name in India) is a small deciduous tree belonging to the family Anacardiaceae and it has $2 n=30$. Flowers of pistachio are apetalous and wind is the pollinating agent for the plant. The edible portion of it is the seed kernel that can be used as an ingredient of sweet meats, confectionery and bakery industries. Along with the propagation through seeds, pistachio can be vegetatively propagated through budding and grafting (Thakur and Rathore 1991). The sex chromosome of pistachio was identified by meiotic study (Harandi and Ghaffari 2001) whereas karyotyping revealed heteromorphic (XY) sex chromosomes in male pistachio plants (Tilkat et al. 2011).

In the last decade of twentieth century, an attempt was made to identify sex-specific molecular marker in $P$. vera using 700 different primers comprising of oligonucleotide decamer. Out of these tested RAPD primers, only one primer (OPO08) produced a 945 bp fragment and the band was only found from the female samples (Hormaza et al. 1994). Another study found sex-specific amplification using nine different ISSR markers and out of them only two primers, (AC) ${ }_{8} \mathrm{CG}$ and $(\mathrm{AC})_{8} \mathrm{TA}$, were able to discriminate between the female and male plants of $P$. vera showing some femalespecific amplifications (Ehsanpour et al. 2008). Molecular marker based sex determination approach was taken for different pistachio species (P. atlantica Desf. subsp. mutica, $P$. khinjuk, and $P$. vera subsp. sarakhs) using thirty different RAPD primers and out of them only BC1200 showed a female-specific amplification at around 1200 bp (Esfandiyari et al. 2011). Additionally, an SCAR marker was identified in that study which was able to amplify a $300 \mathrm{bp}$ region from the female plant only. Very recently, using sex-specific single-nucleotide polymorphism (SNP) markers and restriction site associated DNA (RAD) sequencing technique, Kafkas et al. (2015) identified eight loci regarding sex differentiation in pistachio; finally, they identified four perfect sex distinguishing markers by high-resolution melting (HRM) analysis.

\section{Date palm (Phoenix dactylifera L.)}

Date palm ( $P$. dactylifera L.) or khajur (common name in India) is from the family Arecaceae/Palmae/Palmaceae and since ancient time it is cultivated as fruit tree and known as 
'Tree of Life' by the ancient people (Nath et al. 2008). It has $2 n=36$ and being dioecious the commercially important date fruits are only borne by the female plants. Six- to eight-year-old trees start flowering when sex differentiation can be done visually (Mathew et al. 2014). Cherif et al. (2013) found a non-recombining region in the date palm genome confirming the presence of XY system. Pollination occurs by wind and insects but for better fruit set artificial pollination is done. Crude sugar, molasses, alcoholic beverages are prepared from delicious sweet sap found by tapping date palm tree. Commercially date fruits are used to prepare highly nutritive fruit products; the leaves are used to prepare many things like baskets, brooms, ropes, etc. and the dried leaves as well as trunks are used as fuel also. Although the date fruit is marketed as confectionery all over the world, the demand for fresh fruit especially in the deserts remains high. The fruit is a rich source of tannin which is antiinfective, antiinflammatory and antihemorrhagic, and along with that many other antioxidants like beta-carotene, lutein and zeaxanthin are also found in date fruit that can prevent cancer. Additionally, the dietary fibre present in date fruit can prevent LDL cholesterol absorption in the gut (Dada et al. 2012).

Different researchers identified a number of RAPD primers for sex identification in date palm. One RAPD primer amplified two unique alleles of 600 and $750 \mathrm{bp}$ for differentiating the male and female plants, respectively (Singh et al. 2006), whereas another group was able to identify five sex-specific ( 3 for female and 2 for male) markers using three different RAPD primers (Younis et al. 2008). Additionally, Younis et al. (2008) also reported five different male-specific amplification (of about 340, 1010, 375,590 and 920 bp long) using five different ISSR primers. Another attempt was made to identify sex-specific microsatellite markers from date palm and 14 simple sequence repeat (SSR) primer pairs were used to screen 34 cultivars of date palm (Elmeer and Mattat 2012). Out of 254 numbers of detected microsatellite loci, 22 were found to identify $75 \%$ male samples of date palm. Later on, Dhawan et al. (2013) screened 100 RAPD primers and 104 ISSR primers for sex determination in date palm and identified single RAPD (OPA-02) primer amplifying about $1.0 \mathrm{~kb}$ DNA band only from the DNA samples of the male date palms. By cloning and sequencing of that RAPD band, they designed SCAR primer pair for assured sex differentiation of date palm which amplified a $406 \mathrm{bp}$ amplicon in both male and female plants and a $354 \mathrm{bp}$ fragment in males only. Another group reported two different approaches regarding date palm sex discrimination (Al-Mahmoud et al. 2012). In the first approach, they used PCR-based RFLP analysis and in the second approach they did only PCR using the availability of high heterogeneity in the sexlinked region and no restriction digestion was performed in that approach. Although they found different polymorphisms among the male and female date palms at their early growth stages using both of these approaches, the PCR-RFLP approach was more reliable compared to the PCR only method. Recently, start codon targeted polymorphism (SCOT) and RAPD analyses revealed two SCoT primers (SCoT36 and SCoT41) and four RAPD primers (OP-A11, OP-M11, OP-O07 and OP-S07) showing differential sex-specific banding pattern in date palm (Sami et al. 2014). Two SCoT primers, SCoT41 and SCoT36, identified single female-specific amplification for each of them at around 1150 and $850 \mathrm{bp}$, respectively whereas four different RAPD primers exhibited three female-specific and two male-specific amplifications of different sizes (Sami et al. 2014).

\section{Palmyra palm (Borassus flabellifer L.)}

Palmyra palm (B. flabellifer L.) or taar (common name in India) is an underexploited tree belonging to the family Arecaceae and usually found growing almost wild in every type of wasteland. It is propagated from seeds. It is allotetraploid and the somatic chromosome number is $2 n=36$ ( $x=8$ or 9 ). The male and female have XY and $\mathrm{XX}$ pair of sex chromosomes, respectively. The male spadix contains 20,000-25,000 florets while the female spadix has 30-75 flowers. The pollens are borne by insects as well as wind and the fertilized flower takes 120-130 days to become matured fruit (Chattopadhyay and Bose 2006). A delicious sugary sap is obtained on tapping both the male or female spadices which can be fermented into toddy (country liquor) or boiled down into jaggery, sugar, molasses, vinegar, etc. The edible parts are the endosperm of the tender fruit and the mesocarp (pulp) of the ripe fruit. Tapping sap and the tender fruit endosperm are natural coolants, while the fleshy roots and the young bud present inside the tree apex are also eaten as a diuretic. Additionally, the leaves are used for thatching purposes and the leaves as well as fibres are utilized for various handicraft preparations (Chattopadhyay and Bose 2006; Thiruchitrambalam and Shanmugam 2012) while the trunk is used as wood, especially for making poles. Due to diverse utilization of the whole plant, the palmyra palm is popularly known as 'Tree of Life'. In spite of the importance of this plant, the identification of the sex of this plant is very problematic at early growth stages. To escape the long waiting period (12-15 years) for identification of the sex of palmyra palm, very little work has been carried out using molecular markers. One male-specific RAPD primer was identified and it was found to produce a polymorphic DNA band of $\sim 600 \mathrm{bp}$ in the male plant (George et al. 2007). Further study by the same group was carried out for 
early determination of sex in one, two and three-seeded fruits of B. flabellifer L. using the same primer as before (George and Karun 2011).

\section{Rattan palm}

Rattan palm or Calamus species, belonging to the family Palmae, is another important dioecious plant predominantly grown in tropics and subtropics. Next to bamboo, rattans are spiny palms producing important non-wood forest products worldwide (Xu et al. 2000) and bear typical scaly fruits (Sarmah and Sarma 2011). Rattans are acknowledged as 'green gold' for their valuable economic characters like appearance, lightness, strength, flexibility as well as durability (Mohan and Tandon 1997). There is no record regarding sex chromosomes in Calamus genus. They have usually chromosome numbers $2 n=2 x=26$ (Sarkar and Datta 1985; Roser 1994) but C. palustris Griff. with $2 n=2 x=28$ is an exception (Indira and Anto 2002). C. simplicifolius has wordwide acceptance for high-quality canes suitable for furniture and handicraft making and also for its shoots which is consumed as vegetable ( $\mathrm{Li}$ et al. 2010). Among different species of rattan palm, C. tenuis Roxb. is predominant in Indian subcontinent (Sarmah and Sarma 2011).

A few groups of researchers worked on the molecular markers for sex identification in Calamus species. A malespecific RAPD primer (S1443), producing $500 \mathrm{bp}$ fragment, was developed by Yang et al. (2005) in C. simplicifolius. In the same species, utilizing an RAPD primer, $\mathrm{Li}$ et al. (2010) constructed a male-specific SCAR marker (CsMale1) producing $509 \mathrm{bp}$ amplicon and that possibly represented a coding genomic region due to the presence of two open reading frames in that sequence. Another group identified an ISSR primer with the sequence (AAG) $)_{5} \mathrm{CC}$ and that could amplify $600 \mathrm{bp}$ fragment in female $C$. tenuis Roxb. only but not in the male one (Sarmah and Sarma 2011).

\section{Mulberry (Morus spp.)}

There are four important species of mulberry: Morus alba L. (white mulberry), M. rubra L. (red mulberry), M. nigra L. (black mulberry) and M. microphylla Buckl. (little-leaf mulberry) and they belong to the family Moraceae. Generally, mulberry plants are dioecious in nature, but some monoecious branches can be present in a plant (Barbour et al. 2008). Bhattacharya and Ranade (2001) reported several physiological and biochemical factors causing different sex types of mulberry viz. female, male as well as hermaphrodite flowers bearing monoecious type or dioecious type. Both white and red mulberry plants have $2 n=2 x=28$ chromosome constitution, but black type has $2 n=22 x=308$ (Ottman 1987). In India, mulberry is economically important to rear the silkworm (Bombyx mori L.) larvae that feed on the leaves. Mulberry wood can be utilized for making furniture and sport items while paper can be made from the bark of the tree. The ripe fruit is also taken as delicious fruit that can cure throat infection, purify blood and control fever. It has been reported that nerve tonic can be prepared from the bark of mulberry (Nath et al. 2008).

Very little work has been done for identifying the sex of mulberry by molecular means. A study on diversification of mulberry using ISSR and RAPD molecular markers identified an ISSR marker (ISSR-825.450) having the sequence $(\mathrm{AC})_{8} \mathrm{~T}$ associated with the female sex only, whereas an RAPD marker (OPY-15.1200) showed about 1200 bp amplification only in male plants (Vijayan et al. 2009).

\section{Kiwifruit (Actinidia deliciosa var. deliciosa)}

Chinese gooseberry or kiwifruit (Actinidia deliciosa var. deliciosa) comes under the family Actinidiaceae and it is also called China's miracle fruit and Horticultural wonder of New Zealand. It is a perennial vine and can be commercially propagated by softwood cutting as well as from the seed (Rathore 1991). In India, kiwifruit was introduced in 1960s in parts of the Himalayan region where it performed successfully (Dadlani et al. 1971). There are 60 species of the genus Acnidia but A. deliciosa var. deliciosa and A.chinensis are the only two species bearing edible fruits. Furthermore, A. deliciosa (A. Chev.) C.F. Liang et A.R. Ferguson, commonly known as kiwifruit, is the only species cultivated all over the world (Sharma and Shirkot 2004). The diploid $(2 n=58)$ species $A$. chinensis is the progenitor of $A$. deliciosa var. deliciosa $(2 n=6 x=174)$. XY-type system exists in Actinidia with heterogametic male (Harvey et al. 1997); the sex chromosomes in female

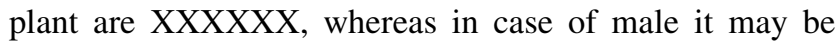
either XXXXXY or XXXXYY (McNeilage 1997; Gill et al. 1998; Shirkot et al. 2002). The fruit is refreshing and has high nutritive as well as medicinal value. The kiwifruit is the rich source of antioxidants and an excellent source of potassium, folate and vitamin C and E (Ferguson 1990; Ferguson and MacRae 1992; Wang et al. 1996; Shirkot et al. 2002).

Kiwifruit is very popular in low and mid-Himalayan region and for successful breeding of this plant identification of male and female genotypes is very crucial before orchard plantation. In twentieth century, two different RAPD primers were selected showing differential banding pattern between male and female genotypes of kiwifruit 
and subsequently SCAR markers were developed (Gill et al. 1998). SCAR marker generated from one of the RAPD (SmX) was converted to a dominant marker, whereas the SCAR marker generated from another one (SmY) failed to show any polymorphism between male and female plants. Later on, another group of researchers identified two male-specific and six female-specific RAPD markers in this fruit crop (Shirkot et al. 2002).

\section{Screwpine (Pandanus species)}

The screwpine or Pandanus species, usually called kewda in India, is a dioecious perennial species predominantly found in coastal regions. It belongs to the family Pandanaceae. The somatic chromosome complement is $2 n=60$ and the female plants with the $6.15 \mathrm{pg}$ genome, are bigger than the male ones possessing $5.09 \mathrm{pg}$ genome (Panda et al. 2010). It is readily propagated from seeds but farmers generally do stem cuttings. The plant can grow in wild withstanding drought, strong wind and salt and it is traditionally used by the farmers of India. The leaves are used in making baskets, mats, hats, and roof thatch. The leaves of some species are as fragrant as basmati rice and hence it is used as a flavouring agent in the cuisines. The aromatic essential oil $(r h u)$ is found from the inflorescence of the male plant. It has several medicinal properties such as the fresh leaves are used to treat sore throat and oil prepared from the young leaves is applied to cure burns while the bark is used in curing diarrhoea, dysentery and enteritis. The powder of the roots is used in treating leucorhoea, absess and oedema and to prevent miscarriage among the tribal community. Fibres extracted from the aerial roots are used to make cords and brushes and some species are used as starchy food sources. Chong et al. (2012) induced apoptosis on non-hormone dependent breast cancer cell with the application of ethanol extract of $P$. amaryllifolius leaves, hence there is anticancerous property in Pandanus leaves.

Very negligible work has been carried out in this crop regarding the sex determination at molecular level. For early determination of sex, Vinod et al. (2007) converted a 1263 bp amplicon generated from a male-specific RAPD primer (OPD-08) into an SCAR marker (MSSR-01) of 976 bp size in P. fascicularis L. Another group reported two male-specific RAPD markers viz., OPA-12 and OPN18 producing 1150 and $600 \mathrm{bp}$ fragment, respectively, in $P$. tectorius Parkinson (Panda et al. 2010).

\section{Jojoba [Simmondsia chinensis (Link) Schneider]}

Jojoba [Simmondsia chinensis (Link) Schneider] belongs to the family Simmondsiaceae and it is a dioecious shrub especially acclimatized for the desert and it is an emerging cash crop in India, producing commercially valuable seeds. In 1978 Jojoba was introduced from Israel into India. The properties of the liquid wax stored in the seeds resemble to the spermaceti of the sperm whale which can be an alternative to the petro-products as well as lubricants for heavy machinery and are used in cosmetic, pharmaceutical and plastic industries. The seed wax of jojoba has some outstanding physical properties with highest limit viz. viscosity index, flash and fire points, dielectric constant, stability and freezing point. The wax can withstand repeated heating to temperatures above $285{ }^{\circ} \mathrm{C}$. As jojoba oil is non-toxic, biodegradable and quite stable, it is used in making detergent, leather, plastic, pharmaceutical and cosmetic products worldwide. In desert areas, the jojoba plant provides shade from its canopy and eliminates windy erosion. The seed is the main prapagule for jojoba and the plant takes 3-4 years to start flowering. Jojoba is a slow developing plant showing a male dominated (male:female::5:1) population (Agrawal et al. 2007). Due to this male biased population and the ability of one male to pollinate many females in jojoba, the Indian farmers have to eliminate a huge number of male plants for maximizing the number as well as growth of commercially important female plants.

Determination of sex in jojoba at the juvenile stage has immense importance in terms of commercial aspects. Although sexual differentiation of jojoba seedlings cannot be done cytologically since jojoba sex chromosomes are not distinguishable through cytological methods (Hosseini et al. 2011), a number of molecular markers have been employed for determination of sex in jojoba. Molecular study by Agrawal et al. (2007) identified a male-specific RAPD marker (OPG-05) producing 1400 bp amplicon in $S$. chinensis (Link) Schneider. Another study documented two male-specific and one female-specific RAPD markers along with PCR-based sex determination in jojoba by sexdetermining region $\mathrm{Y}$ (Sry) gene primers and random primers (Mohasseb et al. 2009). Hosseini et al. (2011) identified one female-specific marker (F1) producing $460 \mathrm{bp}$ fragment and one male-specific RAPD marker (F10) producing $680 \mathrm{bp}$ fragment in S. chinensis cv. Arizona. Further researches developed male-specific 525 and $325 \mathrm{bp}$ AFLP markers utilizing EcoRI-GC/MseI-GCG and EcoRITAC/MseI-GCG primer sets, respectively, and a femalespecific 270 bp AFLP marker utilizing EcoRI-TAC/MseIGCG primer set (Agarwal et al. 2011). Sharma et al. (2008) produced a male-specific ISSR having sequence $(\mathrm{AG})_{8} \mathrm{~T}$ producing $1200 \mathrm{bp}$ fragment in S. chinensis (Link) Schneider, whereas the same ISSR primer amplified of around $1.1 \mathrm{~kb}$ in male jojoba plants by Jangra et al. (2014) and subsequently converted it into an SCAR marker (GenBank accession number HQ166029.1) producing $1000 \mathrm{bp}$ fragment. Heikrujam et al. (2014a, 2014b) successfully 
converted two male-specific ISSR markers viz. (CA) ${ }_{8} \mathrm{G}$ producing $1500 \mathrm{bp}$ fragment and $(\mathrm{CAC})_{3} \mathrm{GC}$ producing $1300 \mathrm{bp}$ fragment into male locus-specific STS markers, STS 807 of size $800 \mathrm{bp}$ (JMSM) and STS VIS11 of size 584 bp in S. chinensis (Link) Schneider.

\section{Yam (Dioscorea species)}

Yam (Dioscorea species) is well known as ratalu in India and it belongs to the Dioscoreaceae family. It is a deciduous perennial herbaceous vine and is considered as a crop for subsistence agriculture. Yam is propagated vegetatively from tuberous roots and also through vine cutting while some species produce bulbils in leaf axils also. The axillary spikes bear the female flowers whereas the male flowers arise on long axillary panicle. Bhowmick et al. (1993) reported that as the basic chromosome number $(x)$ is 9 or 10 , the ploidy level varies from diploid onwards. Another group documented $x=10$ and they also mentioned the presence of one or two extra chromosomes (B chromosomes) as large as the nuclear chromosomes in yam (Dansi et al. 2000). According to Bhat and Bindroo (1980), the male and female plants of $D$. deltoidea Wall. have homomorphic (ZZ) and heteromorphic sex chromosomes (ZW), respectively. In contradiction to that, another group suggested that the male yam plant might be of heterogametic sex (XY) while the female plants would be of homogametic sex (XX) in nature (Terauchi and Kahl 1999).

The edible yams are D. alata L., D. esculenta (Lour.) Burk. and D. rotundata (L.) Poir. Starchy tuber of yam is consumed after roasting and boiling and it can also be used to produce chips, flakes and flour. There are many poisonous yams that are used as insecticide or as an aid in hunting, fishing as well as arrow poisoning and clarified tubers can be consumed as famine food also (Bhowmick et al. 1993). Dutta (2015) reported several medicinal properties of yam. Yam tuber can be used as coolant for lowering body temperature and alcohol can be prepared from yam tuber as well. Most species of yam have steroid sapogenins like diosgenin and glucoside saponin from which many steroidal hormones are manufactured and used as antiinflammatory, androgenic, estrogenic and contraceptive drugs. Yam bulbils are used to cure typhoid in children while the tubers maintain kidney functions, reduce blood cholesterol, regulate female sex hormones, reduce body weight and used against chronic diarrhoea, diabetes, tuberculosis, digestive disorders as well as respiratory disorders. Additionally, it can be used to prevent early miscarriage and it is useful for labour pain also. It is used for the treatment of insect, snake or scorpion bites. The paste prepared from yam tuber can be a good remedy for various skin diseases, leprosy, gonorrhoea and wounds due to cancer. For quick recovery of fractured bones of animals, tuber decoction is applied.

Very limited work has been conducted for identifying the sex-specific marker in yam. An approach was taken for mapping $D$. tokoro genome using 271 AFLPs and 5 STSs, along with one biochemical and one phenotypic marker. The study identified 10 AFLP markers showing heterozygosity only in the male parent that depicted tight linkages of those molecular markers with the sex to their offspring (Terauchi and Kahl 1999).

\section{Hemp (Cannabis sativa L.)}

Hemp (C. sativa L.) is a dioecious species from the family Cannabaceae. It is one of the ancient plants adopted for its fibre and medicinal values as well as for its utility as an addictive and psychoactive drug. Hemp is also valued in paper industries and for the oil present in the seeds. According to Mandolino et al. (1999), hemp has chromosome number $2 n=20$. In general, $C$. sativa males are preferred over females for fibre quality (Horkay and Bocsa 1996). The females are homomorphic (XX) while the males are heteromophic (XY) in nature with subtelocentric and strongly heterochromatic $\mathrm{Y}$ chromosome rich in repetitive sequences (Moliterni et al. 2004). This Y chromosome typically has a satellite at the short arm end and the extra genome size in male (1683 Mbp) over the female (1636 Mbp) is due the long arm of the $\mathrm{Y}$ chromosome (Sakamoto et al. 1998). Moreover, the X chromosome, submetacentric in nature, bears a satellite at its short arm end. An X:autosome dosage controls sex determination in C. sativus (Westgaard 1958; Grant et al. 1994). Truta et al. (2002) found a richer spectrum of esterase as well as peroxidase isoenzyme in male plants than the females. $C$. sativus has flexibility towards bearing bisexual flowers, i.e. monoecious plants can be found along with dioecious ones. Monoecious cultivars of hemp are useful in seed production and stem harvesting. Although there are no specific reports regarding the chromosome of monoecious hemp (Moliterni et al. 2004), it has been reported that the monoecious hemp cultivars have the XX constitution with a genetic basis for sex expression (Faux et al. 2014).

Several studies were carried out for determining the sex in this controversial crop. Sakamoto et al. (1995) reported two RAPD primers producing 500 and 730 bp amplicons specific for male sex; and the 730 bp DNA fragment was named MADC1 (male-associated DNA sequence in $C$. sativa). FISH by Sakamoto et al. (2000), using MADC1 and its flanking DNA as probes, revealed that a specific LINE-like retrotransposon accumulated at the terminal region of the long arm of the $\mathrm{Y}$ chromosome. Another

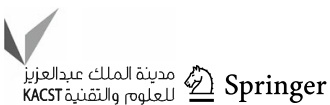


group also reported a male-specific 400 bp RAPD marker (MADC2) and converted it into an SCAR marker producing $390 \mathrm{bp}$ amplicon (Mandolino et al. 1999). Sakamoto et al. (2005) found two male sex-linked RAPD (MADC3 and MADC4) markers encoding gag/pol polyproteins of copia-like retrotransposon and generating a doublet signal at the long arm end of $\mathrm{Y}$ chromosomes when used as probe in FISH study. They also reported that the heteromorphism in the sex chromosome might be due to the accumulation of retrotransposable elements on the $\mathrm{Y}$ chromosome. Heretofore, two RAPD markers viz. MADC5 and MADC6 (producing 961 and $151 \mathrm{bp}$ fragments, respectively) specific to the male plants were converted into SCAR markers by Törjék et al. (2002) and those SCAR markers were able to generate 323 and $119 \mathrm{bp}$ amplicon, respectively.

\section{Conclusion and outlook}

The system of sex identification in many underutilized dioecious plants remains unexplained till date; probably owing to the fact that majority of the domesticated plants are monoecious. The wild relatives of black pepper $(P$. nigrum L.) and wild grape (Vitis vinifera subsp. Sylvestris) are dioecious but their cultivated forms are bisexual and famous worldwide. In addition to that, most of the cultivated types of black pepper are protogynous with female phase preceding the male phase by few days to few weeks (Ravindran et al. 2000). The spinach, (Spinacia oleracea), belonging to the family Amaranthaceae, is another popular dioecious vegetable; but a monoecious plant, from the same family, Beta vulgaris or palak or spinach beet is dominant in Indian market substituting the spinach. The strawberry species are generally dioecious but the common cultivated strawberry (Fragaria $\times$ ananassa) belonging to Rosaceae (Gantait et al. 2010) is a hybrid plant and is monoecious in nature. The papaya is generally a monoecious species but it behaves as trioecious. In India, there is a trend to impose stress to the rarely found non-bearing papaya plant, which is supposed to be male, either by deheading or inserting wooden stick into the stem; the plant starts fruiting later on i.e., the plant converts itself into the most common monoecious form. Obviously, there is an indication of sex reversal and it should be an important area of research in near future. Hence, there is a wide extent to be explored concerning the actual mechanism of dioecy, monoecy or trioecy in plants and more reliable and robust molecular markers are needed to sexually discriminate crops at an early stage. This review will be of significant to execute different strategies taken with respect to the sex determination of commercially important dioecious crops in India and it will provide recent updates regarding the importance as well as sex-oriented studies in those crops.

Acknowledgements The authors would like to acknowledge Directorate of Research and Department of Genetics and Plant Breeding, Bidhan Chandra Krishi Viswavidyalaya, West Bengal, India for providing library assistance for preparation of this review article.

\section{Compliance with ethical standards}

Conflict of interest We, the authors of this article, declare that there is no conflict of interest and we do not have any financial gain from it.

\section{References}

Adhikari S, Saha S, Bandyopadhyay TK, Ghosh P (2014) Identification and validation of a new male sex-specific ISSR marker in pointed gourd (Trichosanthes dioica Roxb.). Sci World J (Article ID 216896). doi:10.1155/2014/216896

Agarwal M, Shrivastava N, Padh H (2011) Development of sexlinked AFLP markers in Simmondsia chinensis. Plant Breed 130:114-116

Agrawal V, Sharma K, Gupta S, Kumar R, Prasad M (2007) Identification of sex in Simmondsia chinensis (jojoba) using RAPD markers. Plant Biotechnol Rep 1:207-210

Ahire YR, Deokule SS (2012) Screening of allelopathic activity of Momordica dioica and Mukia maderaspatana. Res Rev 1:15-21

Ainsworth C (2000) Boys and girls come out to play: the molecular biology of dioecious plants. Ann Bot 86:211-221

Ainsworth C, Rahman A, Parker J, Edwards G (2005) Intersex inflorescences of Rumex acetosa demonstrate that sex determination is unique to each flower. New Phytol 165:711-720

Al-Mahmoud ME, Al-Dous EK, Al-Azwani EK, Malek JA (2012) DNA-based assays to distinguish date palm (Arecaceae) gender. Am J Bot 99:e7-e10

Aoki H, Kieu NT, Kuze N, Tomisaka K, Chuyen NV (2002) Carotenoid pigments in gac fruit (Momordica cochinchinensis Spreng.). Biosci Biotechnol Biochem 66:2479-2482

Banerjee NS, Prasad M, Das MR (1999) Male-sex-associated RAPD markers in Piper longum. Curr Sci 77:693-697

Banu SG, Kumar G, Rajasekara PM (2007) Cholesterol-lowering activity of the aqueous fruit extract of Trichosanthes dioica Roxb. (L.) in normal and streptozotocin diabetic rats. J Clin Diagn Res 1:561-569

Baratakke RC, Patil CG (2009) Identification of a RAPD marker linked to sex determination in Momordica dioica Roxb. Ind J Genet 69:254-255

Barbour JR, Read RA, Barnes RL (2008) Moraceae-Mulberry family Morus L. Mulberry. In: Bonner FT, Karrfalt RP (eds) United States Department of Agriculture Forest Service Agriculture Handbook 727-The Woody Plant Seed Manual, pp 728-732

Barrett SCH (2002) The evolution of plant sexual diversity. Nat Rev Genet 3:274-284

Barrett SCH (2013) The evolution of plant reproductive systems: how often are transitions irreversible? Proc Roy Soc Bot 280:20130913. doi:10.1098/rspb.2013.0913

Bergero R, Qiu S, Forrest A, Borthwick H, Charlesworth D (2013) Expansion of the pseudoautosomal region and ongoing recombination suppression in the Silene latifoliasex chromosomes. Genetics 194:673-686

Bharathi LK, Munshi AD, Vinod Chandrashekaran S, Behera TK, Das AB, John KJ, Vishalnath (2011) Cytotaxonomical analysis 
of Momordica L. (Cucurbitaceae) species of Indian occurrence. J Genet 90:21-30

Bhat BK, Bindroo BB (1980) Sex Chromosomes in Dioscorea deltoidea Wall. Cytologia 45:739-742

Bhattacharya E, Ranade SA (2001) Molecular distinction amongst varieties of mulberry using RAPD and DAMD profiles. BMC Plant Biol 1:3-10

Bhowmick BK, Nanda S, Nayak S, Jha S, Joshi RK, Bose TK, Maharana T, Sen H (1993) Yam. In: Bose TK, Som MG, Kabir J (eds) Vegetable crops. Naya Prokash, Kolkata, pp 879-888

Bhowmick BK, Nanda S, Nayak S, Jha S, Joshi RK (2014) An APETALA3 MADS-box linked SCAR marker associated with male specific sex expression in Coccinia grandis (L.) Voigt. Sci Hortic 176:85-90

Charlesworth B (1991) The evolution of sex chromosomes. Science 251:1030-1032

Chattopadhyay PK, Bose TK (2006) Palmyra palm. In: Parthasarathy VA, Chattopadhyay PK, Bose TK (eds) Plantation crops (Volume 2). Naya Udyog, Kolkata, pp 493-511

Cherif E, Zehdi S, Castillo K, Chabrillange N, Abdoulkader S, Pintaud JC et al (2013) Male-specific DNA markers provide genetic evidence of an XY chromosome system a recombination arrest and allow the tracing of paternal lineages in date palm. New Phytol 197:409-415

Chirathaworn C, Kongcharoensuntorn W, Dechdoungchan T, Lowanitchapat A, Sa-Nguanmoo P, Poovorawan Y (2007) Myristica fragrans Houtt. methanolic extract induces apoptosis in a human leukemia cell line through SIRT1 mRNA downregulation. J Med Assoc Thail 90:2422-2428

Chong HZ, Yeap SK, Rahmat A, Akim AM, Alitheen NB, Othman F, Gwendoline-Ee CL (2012) In vitro evaluation of Pandanus amaryllifolius ethanol extract for induction of cell death on nonhormone dependent human breast adenocarcinoma MDA-MB231 cell via apoptosis. BMC Complement Altern Med 12:134-141

Dada M, Nwawe CN, Okere RA, Uwubanmwen IO (2012) Potentials of date palm tree to the Nigerian economy. World J Agri Sci 8:309-315

Dadlani SA, Singh BP, Kazim M (1971) Chinese gooseberry, a new fruit plant. Indian Hort 16:13-15

Dansi A, Pillay M, Mignouna HD, Dainou O, Mondeil F, Moutairou K (2000) Ploidy level of the cultivated yams (Dioscorea cayenensis/D. rotundata complex) from Benin Republic as determined by chromosome counting and flow cytometry. Afr Crop Sci J 8:355-364

Dhawan C, Kharb P, Sharma R, Uppal S, Aggarwal RK (2013) Development of male-specific SCAR marker in date palm (Phoenix dactylifera $\mathrm{L}$.). Tree Genet Genomes 9:1143-1150

Dutta B (2015) Food and medicinal values of certain species of Dioscorea with special reference to Assam. J Pharmacogn Phytochem 3:15-18

Ehsanpour AA, Tavassoli M, Arab L (2008) Sex determination of Pistacia vera L. using ISSR markers. Malaysian Appl Biol 37:25-28

Elmeer K, Mattat I (2012) Marker-assisted sex differentiation in date palm using simple sequence repeats. 3 Biotech 2:241-247

Esfandiyari B, Davarynejad GH, Shahriari F, Kiani M, Mathe A (2011) Data to the sex determination in Pistacia species using molecular markers. Euphytica 185:227-231

Farooqi AA, Sreeramu BS, Srinivasappa KN (2005) Cultivation of spice crops. Universities Press India Pvt. Ltd., Hyderabad, pp 250-256

Faux AM, Berhin A, Dauguet N, Bertin P (2014) Sex chromosomes and quantitative sex expression in monoecious hemp (Cannabis sativa L.). Euphytica 196:183-197

Ferguson AR (1990) Kiwifruit (Actinidia). Acta Hortic 290:601-653
Ferguson AR, MacRae EA (1992) Vitamin C in Actinidia. Acta Hortic 297:481-487

Fraser LG, Tsang GK, Datson PM, De Silva HN, Harvey CF, Gill GP, Crowhurst RN, McNeilage MA (2009) A gene-rich linkage map in the dioecious species Actinidia chinensis (kiwifruit) reveals putative $\mathrm{X} / \mathrm{Y}$ sex-determining chromosomes. BMC Genom 10:102-116

Gantait S, Mandal N, Bhattacharyya S, Das PK (2010) Sustainable in vitro propagation and clonal fidelity in strawberry. Int J Plant Dev Biol 4:19-25

Gao WJ, Li RL, Li SL, Deng CL, Li SP (2007) Identification of two markers linked to the sex locus in dioecious Asparagus officinalis plants. Russ J Plant Physiol 54:816-821

George J, Karun A (2011) Marker assisted detection of seed sex ratio in palmyrah palm (Borassus flabellifer L.). Curr Sci 100:922-925

George J, Karun A, Manimekala R, Rajesh MK, Remya P (2007) Identification of RAPD markers linked to sex determination in palmyrah (Borassus flabellifer L.). Curr Sci 93:1075-1077

Ghadge AG, Karmakar K, Devani RS, Banerjee J, Mohanasundaram B, Sinha RK, Sinha S, Banerjee AK (2014) Flower development, pollen fertility and sex expression analyses of three sexual phenotypes of Coccinia grandis. BMC Plant Biol 14:325-339

Gill GP, Harvey CF, Gardner RC, Fraser LG (1998) Development of sex-linked PCR markers for gender identification in Actinidia. Theor Appl Genet 97:439-445

Grant S, Houben A, Vyskot B, Siroky J, Pan WH, Macas J, Saedler H (1994) Genetics of sex determination in flowering plants. Dev Gen 15:214-230

Guha A, Sinha RK, Sinha S (2014) Karyotype and sex expression in Coccinia indica, a dioecious cucurbit. Adv Biol Res 8:244-248

Harandi OF, Ghaffari M (2001) Chromosome studies on pistachio (Pistacia vera L.) from Iran. In: Ak BE (ed) XI GREMPA seminar on pistachios and almonds. CIHEAM, Zaragoza, pp 35-40

Harkess A, Mercati F, Shan HY, Sunseri F, Falavigna A, LeebensMack J (2015) Sex-biased gene expression in dioecious garden asparagus (Asparagus officinalis). New Phytol 207:883-892

Harvey CF, McNeilage MA, Gill GP, Fraser LG (1997) Sex determination in Actinidia 1. Sex-linked markers and progeny sex ratio in diploid A. chinensis. sex. Plant Reprod 10:149-154

Hazra P, Chattopadhyay A, Karmakar K, Dutta S (2011) Pointed Gourd. In: Jain SP (ed) Modern technology in vegetable production. New India Publishing agency, New Delhi, pp 380-393

Heikrujam M, Sharma K, Kumar J, Agrawal V (2014a) Validation of male sex-specific UBC-8071 200 ISSR marker and its conversion into sequence tagged sites marker in jojoba: a high precision oil yielding dioecious shrub. Plant Breed 133:666-671

Heikrujam M, Sharma K, Kumar J, Agrawal V (2014b) Generation and validation of unique male sex-specific sequence tagged sites (STS) marker from diverse genotypes of dioecious JojobaSimmondsia chinensis (Link) Schneider. Euphytica 199:363-372

Heikrujam M, Sharma K, Prasad M, Agrawal V (2015) Review on different mechanisms of sex determination and sex-linked molecular markers in dioecious crops: a current update. Euphytica 201:161-194

Horkay E, Bocsa I (1996) Objective basis for evaluation of differences in fibre quality between male female and monoecious hemp. J Int Hemp Assoc 3:67-68

Hormaza JI, Dollo L, Polito VS (1994) Identification of RAPD marker linked to sex determination in Pistacia vera using bulked segregant analysis. Theor Appl Genet 89:9-13

Hosseini FS, Hassani HS, Arvin MJ, Baghizadeh A, MohammadiNejad G (2011) Sex determination of jojoba (Simmondsia chinensis cv Arizona) by random amplified polymorphic DNA (RAPD) molecular markers. Afr J Biotech 10:470-474 
Hough J, Ågren JA, Barrett SCH, Wright SI (2014) Chromosomal distribution of cytonuclear genes in a dioecious plant with sex chromosomes. Genome Biol Evol 6:2439-2443

Hussain A, Wahab S, Rizvi A, Hussain MS (2011) Macroscopical, anatomical and physico-chemical studies on leaves of Coccinia india Wight and Arn., growing wildly in eastern Uttar Pradesh region of India. Ind J Nat Prod Resour 2:74-80

Ii Y, Uragami A, Uno Y, Kanechi M, Inagaki N (2012) RAPD based analysis of differences between male and female genotypes of Asparagus officinalis. Hortic Sci (Prague) 39:33-37

Indira EP, Anto PV (2002) Karyotype analysis in Calamus palustris Griff. J Bamboo Rattan 1:199-203

Jamsari A, Nitz I, Reamon-Buttner SM, Jung C (2004) BAC derived diagnostic markers for sex determination in asparagus. Theor Appl Genet 108:1140-1146

Jangra S, Kharb P, Mitra C, Uppal S (2014) Early diagnosis of sex in jojoba Simmondsia chinensis (Link) Schneider by sequence characterized amplified region marker. Proc Nat Acad Sci $84: 251-255$

Jiang C, Sink KC (1997) RAPD and SCAR markers linked to the sex expression locus M in Asparagus. Euphytica 94:329-333

Kabir J (1993) Asparagus. In: Bose TK, Som MG, Kabir J (eds) Vegetable crops. Naya Prokash, Kolkata, pp 893-899

Kafkas S, Khodaeiaminjan M, Güney M, Kafkas E (2015) Identification of sex-linked SNP markers using RAD sequencing suggests $\mathrm{ZW} / \mathrm{ZZ}$ sex determination in Pistacia vera $\mathrm{L}$. BMC Genom 16:98-108

Kanno A, Kubota S, Ishino K (2014) Conversion of a male-specific RAPD marker into an STS marker in Asparagus officinalis L. Euphytica 197:39-46

Karmakar K, Sinha RK, Sinha S (2013) Karyological and electrophoretic distinction between sexes of Trichosanthes bracteata. Am J Plant Sci 4:494-497

Khadke GN, Bindu KH, Ravishankar KV (2012) Development of SCAR marker for sex determination in dioecious betel vine (Piper betle L.). Curr Sci 103:712-716

Kumar S, Singh BD, Pandey S, Ram D (2008) Inheritance of leaf and stem morphological traits in pointed gourd (Trichosanthes dioica Roxb.). J Crop Improv 22:225-233

Kumar S, Singh BD, Sinha DP (2012) RAPD markers for identification of sex in pointed gourd (Trichosanthes dioica Roxb.). Ind J Biotech 11:251-256

Kumar S, Kumar R, Sharma V (2014) Genetics of dioecy and causal sex chromosomes in plants. J Genet 93:241-277

Latha PG, Sindhu PG, Suja SR, Geetha BS, Pushpangadan P, Rajasekharan S (2005) Pharmacology and chemistry of Myristica fragrans Houtt.- a review. J Spices Arom Crop 14:94-101

Law TF, Lebel-Hardenack S, Grant SR (2002) Silver enhances stamen development in female white campion (Silene latifolia [Caryophyllaceae]). Am J Bot 89:1014-1020

Li M, Yang H, Li F, Yang F, Yin G, Gan S (2010) A malespecific SCAR marker in Calamus simplicifolius, a dioecious rattan species endemic to China. Mol Breed 25:549-551

Maiti S (2006) Betel vine. In: Parthasarathy VA, Chattopadhyay PK, Bose TK (eds) Plantation crops, vol 2. Naya Udyog, Kolkata, pp 463-491

Mandolino G, Carboni A, Forapani S, Faeti V, Ranalli P (1999) Identification of DNA markers linked to the male sex in dioecious hemp. Theor Appl Genet 98:86-92

Manoj P, Banerjee NS, Ravichandran P (2005) Development of sexassociated SCAR markers in Piper longum L. PGR Newsl 141:44-50

Mathew LS, Spannag M, Al-Malki A, George B, Torres MF, Al-Dous EK et al (2014) A first genetic map of date palm (Phoenix dactylifera) reveals long-range genome structure conservation in the palms. BMC Genom 15:285-294
McNeilage MA (1997) Progress in breeding hermaphrodite kiwifruit cultivars and understanding the genetics of sex determination. Acta Hort 444:72-78

Milewicz M, Sawicki J (2012) Mechanisms of sex determination in plants. Čas Slez Muz Opava (A) 61:123-129

Ming R, Wang J, Moore PH, Paterson AH (2007) Sex chromosomes in flowering plants. Am J Bot 94:141-156

Ming R, Bendahmane A, Renner SS (2011) Sex chromosomes in land plants. Annu Rev Plant Biol 62:485-514

Mishra D, Shukla AK, Tripathi KK, Singh A, Dixit AK, Singh K (2006) Efficacy of application of vegetable seed oils as grain protectant against infestation by Callosobruchus chinensis and its effect on milling fractions and apparent degree of dehusking of legume-pulses. J Oleo Sci 56:1-7

Mohan RHY, Tandon R (1997) Bamboo and rattans: from riches to rags. Proc Nat Acad Sci-India 63:245-267

Mohasseb HBA, Moursy HA, El-Bahr MK, Adam ZM, Solliman M (2009) Sex determination of jojoba using RAPD markers and Sry gene primer combined with RAPD primers. Res J Cell Mol Biol 3:102-112

Moliterni CMV, Cattivelli L, Ranalli P, Mandolino G (2004) The sexual differentiation of Cannabis sativa L., a morphological and molecular study. Euphytica 140:95-106

Nakayama H, Ito T, Hayashi Y, Sonoda T, Fukuda T, Ochiai T, Kameya T, Kanno A (2006) Development of sex-linked primers in garden asparagus (Asparagus officinalis L.). Breed Sci 56:327-330

Nanda S, Kara B, Nayaka S, Jha S, Joshi RK (2013) Development of an ISSR based STS marker for sex identification in pointed gourd (Trichosanthes dioica Roxb.). Sci Hortic 150:11-15

Narasimhan S, Kannan S, Ilango K, Maharajan G (2005) Antifeedant activity of Momordica dioica fruit pulp extracts on Spodoptera litura. Fitoterapia 76:715-717

Nath V, Kumar D, Pandey V (2008) Fruits for the future, Vol 1: well versed arid and semi arid fruits. Satish Serial Publishing House, Delhi

Ottman Y (1987) Rediscovering the realm of fruiting mulberry varieties. Fruit Var J 41:4-7

Panda KK, Sahoo B, Das AB, Pandaa BB (2010) Use of RAPD markers to detect sex differences in Pandanus tectorius Parkinson, an important bioresource plant in Orissa, India. Int Biodivers Sci Ecosyst Serv Manag 6:28-34

Patil CG, Baratakke RC, Sandigwad AM (2012) Development of a RAPD-based SCAR marker for sex identification in Momordica dioica Roxb. Israel J Plant Sci 60:457-465

Pekamwar SS, Kalyankar TM, Kokate SS (2013) Pharmacological activities of Coccinia Grandis: review. J Appl Pharm Sci 3:114-119

Prajapathi ND, Purohit SS, Sharmi AK, Kumar TA (2003) Handbook of medicinal plants: a complete source book. Agrobios (India) Shyam Printing Press, Jodhpur

Rai PK, Jaiswal D, Singh R, Watal G (2008) Glycemic property of Trichosanthes dioica leaves. Pharm Biol 46:894-899

Rai PK, Shukla S, Mehta S, Rai NK, Rai AK, Watal G (2010) Therapeutic phytoelemental profile of Trichosanthes dioica. Adv Mater Lett 1:210-216

Rai MP, Thilakchand KR, Palatty PL, Rao P, Rao S, Bhat HP et al (2011) Piper betel Linn. (betel vine), the maligned southeast asian medicinal plant possesses cancer preventive effects: time to reconsider the wronged opinion. Asian Pacific J Cancer Prev 12:2149-2156

Rathore DS (1991) Kiwifruits. In: Mitra SK, Rathore DS, Bose TK (eds) Temperate fruits. Horticulture and Allied publishers, Kolkata, pp 721-747

Ravindran PN, Nirmal BK, Sasikumar B, Krishnamoorthy KS (2000) Botany and crop improvement of black pepper. In: Ravindran 
PN (ed) Black pepper, Piper nigrum. Harwood Academic Publishers, Amsterdam, pp 23-142

Reamon-Büttner SM, Schondelmaier J, Jung C (1998) AFLP markers tightly linked to the sex locus in Asparagus officinalis L. Mol Breed 4:91-98

Renner SS, Ricklefs RE (1995) Dioecy and its correlates in the flowering plants. Am J Bot 82:596-606

Roser M (1994) Pathways of karylogical differentiation in palms. Plant Syst Evol 189:83-122

Sakamoto KL, Shimomura K, Kamada H, Satoh S (1995) A maleassociated DNA sequence in a dioecious plant, Cannabis sativa L. Plant Cell Physiol 36:1549-1554

Sakamoto K, Akiyama Y, Fukui K, Kamada H, Satoh S (1998) Characterization; genome size and morphology of sex chromosomes in hemp (Cannabis sativa L.). Cytologia 63:459-464

Sakamoto K, Ohmido N, Fukui K, Kamada H, Satoh S (2000) Sitespecific accumulation of a LINE-like retrotransposon in a sex chromosome of the dioecious plant Cannabis sativa. Plant Mol Biol 44:723-732

Sakamoto K, Abe T, Matsuyama T, Yoshida S, Ohmido N, Fukui K, Satoh S (2005) RAPD markers encoding retrotransposable elements are linked to the male sex in Cannabis sativa $\mathrm{L}$. Genome 48:931-936

Samantaray S, Phurailatpam A, Bishoyi AK, Geetha KA, Maiti S (2012) Identification of sex-specific DNA markers in betel vine (Piper betle L.). Genet Resour Crop Evol 59:645-653

Sami SA, Jiming J, Mohamed AM (2014) Identification of novel sexspecific PCR-based markers to distinguish the genders in Egyptian date palm trees. Asia Int J Agri Sci Res 4:45-54

Sarkar AK, Datta N (1985) Cytology of Calamus L. (palmae) as an aid to their taxonomy. Cell Chrom Res 8:69-73

Sarmah P, Sarma RN (2011) Identification of a DNA marker linked to sex determination in Calamus tenuis Roxb., an economically important rattan species in northeast India. Mol Breed 27:115-118

Seefelder S, Ehrmaier H, Schweizer G, Seigner E (2000) Male and female genetic linkage map of hops, Humulus lupulus. Plant Breed 119:249-255

Sharma DR, Shirkot P (2004) Biotechnological interventions for genetic amelioration of Actinidia deliciosa var. deliciosa (kiwifruit) plant. Ind J Biotech 3:249-257

Sharma G, Pandey DN, Pant MC (1990) The biochemical evaluation of feeding Trichosanthes dioica Roxb. seeds in normal and mild diabetic human subjects in relation to lipid profile. Ind J Physiol Pharmacol 34:140-148

Sharma K, Agrawal V, Gupta S, Kumar R, Prasad M (2008) ISSR marker-assisted selection of male and female plants in a promising dioecious crop jojoba (Simmondsia chinensis). Plant Biotechnol Rep 2:239-243

Sheeja TE, Bindu KH, Anto P, Dhanya K, Siju S, Kumar TV (2013) A SCAR marker based method for sex determination in dioecious betel vine (Piper betle). Ind J Agri Sci 83:1409-1410

Shephard H, Parker J, Darby P, Ainsworth CC (1999) Sex expression in hop (Humulus lupulus L. and H. japonicas Sieb. et Zucc.): floral morphology and sex chromosomes. In: Ainsworth CC (ed) Sex determination in plants. BIOS Scientific Publishers, Oxford, pp 137-148

Shephard HL, Parker JS, Darby P, Ainsworth CC (2000) Sexual development and sex chromosomes in hop. New Phytol 148:397-411

Shibu MP, Ravishankar KV, Anand L, Ganeshaiah KN, Shaanker U (2000) Identification of sex-specific DNA markers in the dioecious tree, nutmeg (Myristica fragrans Houtt.). PGR Newslett 121:59-61

Shirkot P, Sharma DR, Mohapatra T (2002) Molecular identification of sex in Actinidia deliciosa var. deliciosa by RAPD markers. Sci Hortic 94:33-39
Shivhare Y, Singour PK, Patil UK, Pawar RS (2010) Wound healing potential of methanolic extract of Trichosanthes dioica Roxb. (fruits) in rats. J Ethnopharmacol 127:614-619

Singh M, Kumar S, Singh AK, Ram D, Kalloo G (2002) Female sexassociated RAPD marker in pointed gourd (Trichosanthes dioica Roxb.). Curr Sci 82:131-132

Singh P, Kharb P, Pandey N, Batra P, Khatak S, Dhillon S et al (2006) RAPD analysis for genetic diversity and identification of sexspecific marker in date palm. Haryana J Hortic Sci 35:232-234

Sinha S, Guha A, Sinha B, Sinha RK, Banerjee N (2007) Average packing ratio and evolution of sex chromosomes in dioecious Coccinia indica and Trichosanthes dioica. Cytologia 72:369-372

Soldatova NA, Khryanin VN (2010) The effects of heavy metal salts on the phytohormonal status and sex expression in Marijuana. Russ J Plant Physiol 57:96-100

Sousa A, Fuchs J, Renner SS (2013) Molecular cytogenetics (FISH, GISH) of Coccinia grandis: a ca. 3 myr-old species of cucurbitaceae with the largest Y/autosome divergence in flowering plants. Cytogenet Genome Res 139:107-118

Talukdar SN, Hossain MN (2014) Phytochemical, phytotherapeutical and pharmacological study of Momordica dioica. Article ID 806082. doi:10.1155/2014/806082

Tamilselvan N, Thirumalai T, Elumalai EK, Balaji R, David E (2011) Pharmacognosy of Coccinia grandis: a review. Asian Pacific J Biomed 1:S299-S302

Telgmann-Rauber A, Jamsari A, Kinney MS, Pires JC, Jung C (2007) Genetic and physical maps around the sex-determining $M$-locus of the dioecious plant asparagus. Mol Genet Genom 278:221-234

Terauchi R, Kahl G (1999) Mapping of the Dioscorea tokoro genome: AFLP markers linked to sex. Genome 42:752-762

Thakur BS, Rathore DS (1991) Pistachios. In: Mitra SK, Rathore DS, Bose TK (eds) Temperate fruits. Horticulture and Allied publishers, Calcutta, pp 451-472

Thiruchitrambalam M, Shanmugam D (2012) Influence of pretreatments on the mechanical properties of palmyra palm leaf stalk fiber-polyester composites. J Reinf Plast Compos 31:1400-1414

Tilkat EA, Namli S, Işikalan Ç (2011) Determination and assesment of the sex chromosomes of male trees of pistachio (Pistacia vera L.) using in vitro culture. Aust J Crop Sci 5:291-295

Törjék O, Buchern N, Kiss E, Homoki H, Finta-Korpelova Z, Bocsa I et al (2002) Novel male specific markers (MADC5, MADC6) in hemp. Euphytica 127:209-218

Truta E, Gille E, Toth E, Maniu M (2002) Biochemical differences in Cannabis sativa L. depending on sexual phenotype. J Appl Genet 43:451-462

Usha R, Indira VS, Jhansi S, Swamy PM (2009) Physiological and molecular variation among the two genders of Piper betel L. Nat Acad Sci Lett 32:93-98

Vijayan K, Nair CV, Chatterjee SN, Caspian J (2009) Diversification of mulberry (Morus indica var. S36), a vegetatively propagated tree species. Env Sci 7:23-30

Vinod MS, Raghavan PS, George S, Parida A (2007) Identification of a sex-specific SCAR marker in dioecious Pandanus fascicularis L. (Pandanaceae). Genome 50:834-839

Viswanathan TV (1995) Medicinal and aromatic plants. In: Chadha KL, Gupta R (eds) Advances in Horticulture. Malhotra Publishing House, New Delhi, pp 373-383

Vuong LT, Franke A, Custer L, Murphy SP (2006) Momordica cochinchinensis Spreng. (gac) fruit carotenoids reevaluated. J Food Compos Anal 19:664-668

Vyskot B, Hobza R (2004) Gender in plants: sex chromosomes are emerging from the fog. Trends Genet 20:432-438 
Wang H, Cao GH, Prior RL (1996) Total antioxidant capacity of fruits. J Agri Food Chem 44:701-705

Wang J, Na J, Yu Q, Gschwend AR, Han J, Zeng F et al (2012) Sequencing papaya $\mathrm{X}$ and $\mathrm{Y}^{\mathrm{h}}$ chromosomes reveals molecular basis of incipient sex chromosome evolution. Proc Nat Acad Sci 109:13710-13715

Westgaard M (1958) The mechanism of sex determination in dioecious plants. Adv Genet 9:217-281

Xu HC, Yin GT, Li YD, Fu JG, Zhang WL (2000) Distribution and utilization of rattans in China. In: Xu HC, Rao AN, Zeng BS, Yin GT (eds) Research on rattans in China, conservation, cultivation, distribution, ecology, growth, phenology, silviculture, systematic anatomy and tissue culture. IPGRI-APO, Serdang
Yang H, Gan S, Yin G, Hu H (2005) Identification of random amplified polymorphic DNA markers linked to sex determination in Calamus simplicifolius C.F.Wei. J Integr Plant Biol 47:1249-1253

Yang S, Kyun NM, Jang JP, Kyung AK, Kim BY, Sung NJ, Oh WK, Ahn JS (2006) Inhibition of protein tyrosine phosphatase 1B by lignans from Myristica fragrans. Phytother Res 20:680-682

Younis RAA, Ismail OM, Soliman SS (2008) Identification of sexspecific DNA markers for date palm (Phoenix dactylifera L.) using RAPD and ISSR techniques. R J Agri Biol Sci 4:278-284

Zheng L, Zhang YM, Zhan YZ, Liu CX (2014) Momordica cochinchinensis seed extracts suppress migration and invasion of human breast cancer ZR-75-30 cells via down-regulating MMP-2 and MMP-9. Asian Pacific J Cancer Prev 15:1105-1110 